\title{
Analysis of the effects of food and of digestive secretions on the small intestine of the rat: III. Mucosal mass, activity of brush border enzymes, and in vivo absorption of galactose, sodium, and potassium
}

\author{
R. ECKNAUER ${ }^{1}$, G. FEYERABEND, AND H. RAFFLER \\ From the Departments of Clinical Chemistry, Surgery, and Clinical Physiology, University of Ulm, Ulm, \\ Federal Republic of Germany
}

SUMMARY A modified Roux-en-y repositioning of rat proximal small intestine resulted in a gut segment (A) exposed only to digestive secretions, but not to food and a gut segment (B) exposed to food, stomach juice and by reflux only to digestive secretions, and a third segment (C) exposed to both, food and digestive secretions.

The changes in segment $\mathrm{A}$ were qualitatively very similar to those occurring after removal of luminal nutrition (intravenous feeding, self-emptying blind loop, and Thiry Vella loop). These findings support the hypothesis that the presence of luminal nutrition is a major factor regulating mucosal mass and enzyme activity in rat proximal small intestine.

The changes in the luminal environment in segment B caused an increase in mucosal mass (in the proximal half only), an increase in sucrase activity which paralleled the increase in mucosal mass, and no change in activity of alkaline phosphatase which in fact was a decrease in activity 'at the cellular level'. Later on the net absorption of sodium and potassium was improved and the disappearance of galactose was unchanged when referred to unit length of small intestine.

In segment $\mathbf{C}$ there was a small increase in mucosal mass, an increase in activity only for alkaline phosphatase, and an improvement of the net absorption of sodium without changes in the disappearance of galactose. These changes were compatible with a more proximal promotion of a distal gut segment.

Extending previous studies (Clarke et al., 1976; Ecknauer et al., 1977a) the present work analyses the changes in mucosal mass, the activity of sucrase and alkaline phosphatase, and the in vivo absorption of galactose, sodium, and potassium one month after creating a modified Roux-en-y repositioning of rat proximal small intestine. To exclude any unspecific changes in the intestinal microflora of the rats subjected to different experimental influences we operated on gnotobiotic rats and kept them in a previously sterilised isolation system.

${ }^{1}$ Address for correspondence: Dr R. Ecknauer, Department of Physiology, University of Texas Health Science Center, P. O. Box 20708, Houston, Texas 77030, USA.

Received for publication 13 March 1978

\section{Methods}

The Roux-en-y repositioning was done as in the previous experiments (Clarke et al., 1976; Ecknauer et al., 1977a, Fig. 1). In the experiments here presented the length of the segments was determined by counting five arcades of vascular supply. A total of 24 gnotobiotic rats of a Wistar strain (Ch-bb, THOM, descendants of gnotobiotic rats associated 1971 with a pentaflora consisting of Lactobacillus acidophilus ATCC 11506, Lactobacillus bifidus, Streptococcus lactis, Streptococcus faecalis ATCC 10541, Escherichia coli, and Fusobacterium symbiosum ATCC 11940) were divided into three groups of eight rats each: un-operated, transsected, and operated. After surgery three rats (one of each group) 


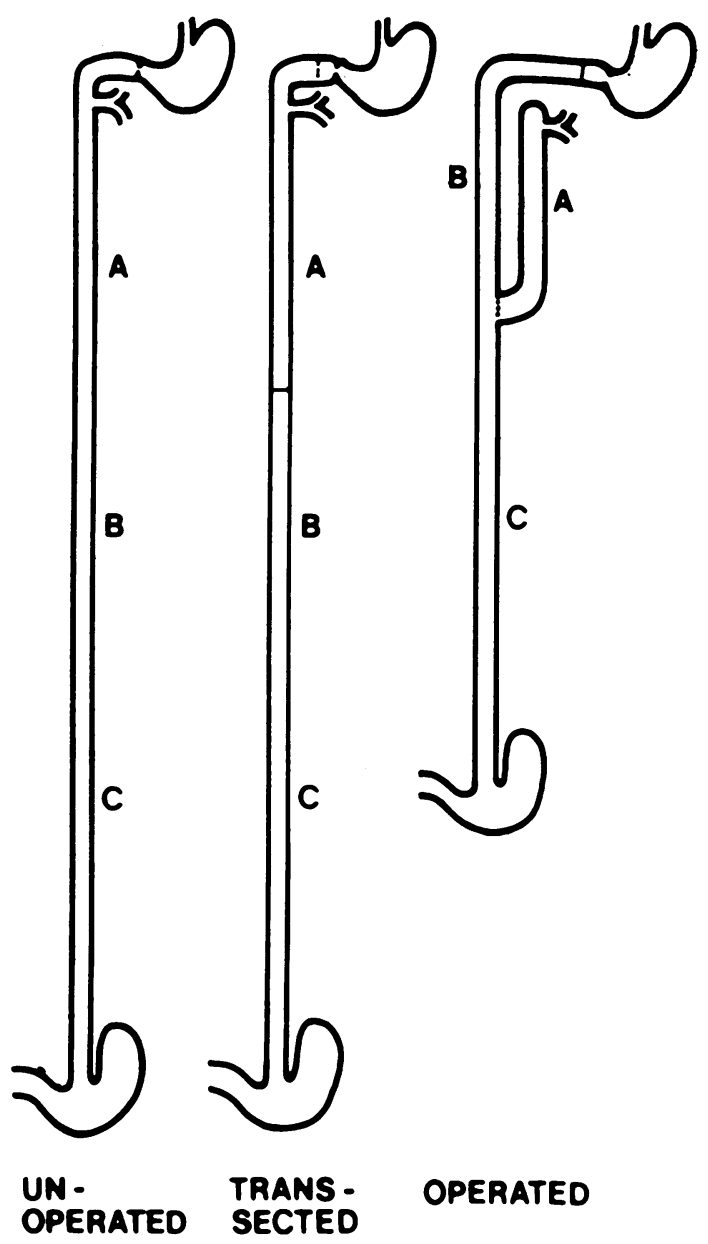

Fig. 1 Disposition of the small intestine. Segment A: first gut segment, which in operated rats contains solely digestive secretions but no food. The part of this segment lying between the papilla Vateri and the ligament of Treitz was not analysed. Segment B: second gut segment starting at the end of segment $A$. In the operated rats the stomach empties into this segment and digestive secretions from pancreas and bile can enter this segment only by reflux. Segment $C$ : third gut segment, which in operated rats is exposed to both food and digestive secretions.

were kept together in a wire mesh bottom cage inside a Trexler plastic isolator. They got sterilised water and sterilised rat chow (Altromin 14/15 fortified, Altromin, Lage Lippe, FRG) ad libitum. Thirty days after surgery the solid food, but not the water, was withdrawn at 17.00 . On the following day, always starting at 09.00 , the rats were anaesthetised with pentobarbital $(50 \mathrm{mg} / \mathrm{kg}$ body weight, intraperitoneally) and the segments $\mathrm{B}$ and $\mathrm{C}$ were perfused simultaneously at a rate of $12 \mathrm{ml} / \mathrm{h}$. After a washout period of 20 minutes the perfusate was collected in five fractions each of 10 minutes' duration. The hydrostatic pressure at the level of the inlet tubing was about $5 \mathrm{~cm}$ fluid, at the level of the outlet tubing about zero. The perfusion fluid was a diluted Ringer solution $\left(\mathrm{Na}^{+} 129 \mathrm{mmol} / \mathrm{l}, \mathrm{K}^{+}\right.$ $3.5 \mathrm{mmol} / 1$, and $\left.\mathrm{Ca}^{++} 2.0 \mathrm{mmol} / \mathrm{l}\right)$ containing 64 mmol D-galactose, $5 \mathrm{ml}{ }^{14} \mathrm{C}$ D-galactose (185 $\mathrm{MBq} / \mathrm{ml}=5 \mu \mathrm{Ci} / \mathrm{ml}, 11 \cdot 1 \mathrm{TBq} / \mathrm{mol}=3 \mathrm{mCi} / \mathrm{mmol}$ ), and $20 \mathrm{mg}$ phenol red in one litre. The osmolality was about $305 \mathrm{mosmol} / \mathrm{kg}$, the $\mathrm{pH}$ about 6.5 . Before the beginning of the perfusion a ligature was performed at the ligament of Treitz to prevent bile and pancreatic juice from entering into segment $A$. At the end of the perfusion the rats were killed by cervical dislocation and the three gut segments were rapidly removed and rinsed thoroughly with $\left(+4^{\circ} \mathrm{C}\right)$ $0.154 \mathrm{~mol} / \mathrm{l}$ saline. The length of the removed segments was measured by stretching them with a $3 \mathrm{~g}$ weight. Still stretched the segments were cut in the middle so that the mucosa could be scraped off separately from the proximal and distal half of each segment. Freezing, drying, storing, and homogenising the mucosa and measuring the concentration of protein and DNA, the activity of sucrase (EC 3.2.1.26) and alkaline phosphatase (EC 3.1.3.1.) all this was done as previously described (Ecknauer et al., 1977a,b). Sodium and potassium concentration were measured by emission flame photometry. The measurement of protein, DNA, sodium and potassium concentration, as well as the measurement of activity of sucrase and alkaline phosphatase, was subjected to a quality control (Ecknauer et al., 1977b). The imprecision within run and between run in our laboratory during the time of this experiment is shown in Table 1.

All data were expressed as arithmetical mean with standard deviation. If there was no significant difference between the variances we used Student's $t$ test for comparison of the means. Otherwise we compared the means by Welch's method (Welch, 1947). Two means $\mu_{1}, \mu_{2}$ were considered significantly different if the hypothesis $\mathrm{H}_{0}: \mu_{1}=\mu_{2}$, which was tested against the alternative hypothesis $\mathrm{H}_{1}: \mu_{1}$ $\neq \mu_{2}$, was rejected at a significance level of $5 \%$ that is, $P<0.05$.

\section{Results}

The initial and final body weight of the three groups of rats were not significantly different. The weight gain in the 30 days after surgery was $121 \pm 21 \mathrm{~g}$, $115 \pm 29 \mathrm{~g}$, and $83 \pm 41 \mathrm{~g}$ in the non-operated, transsected, and operated rats respectively.

Segment A was significantly shorter than the segments $B$ and $C$ but there were no differences in 
the lengths of the corresponding segments between the three animal groups (range of the means of the three groups: A $17-19 \mathrm{~cm}, \mathrm{~B} 23-25 \mathrm{~cm}$, and C 24-28 $\mathrm{cm})$.

\section{MUCOSAL MASS}

Mucosal dry weight, protein, and DNA in the mucosa of the operated rats compared to both non-operated and transsected rats were significantly lower in the proximal half of the segment $A$ and significantly higher in the proximal halves of the segments B and C. In the distal halves of the segments there were no significant differences between the three groups of rats (Fig. 2).

\section{In vivo ABSORPTION}

In segment $B$ we could not find any differences in disappearance of galactose between the three
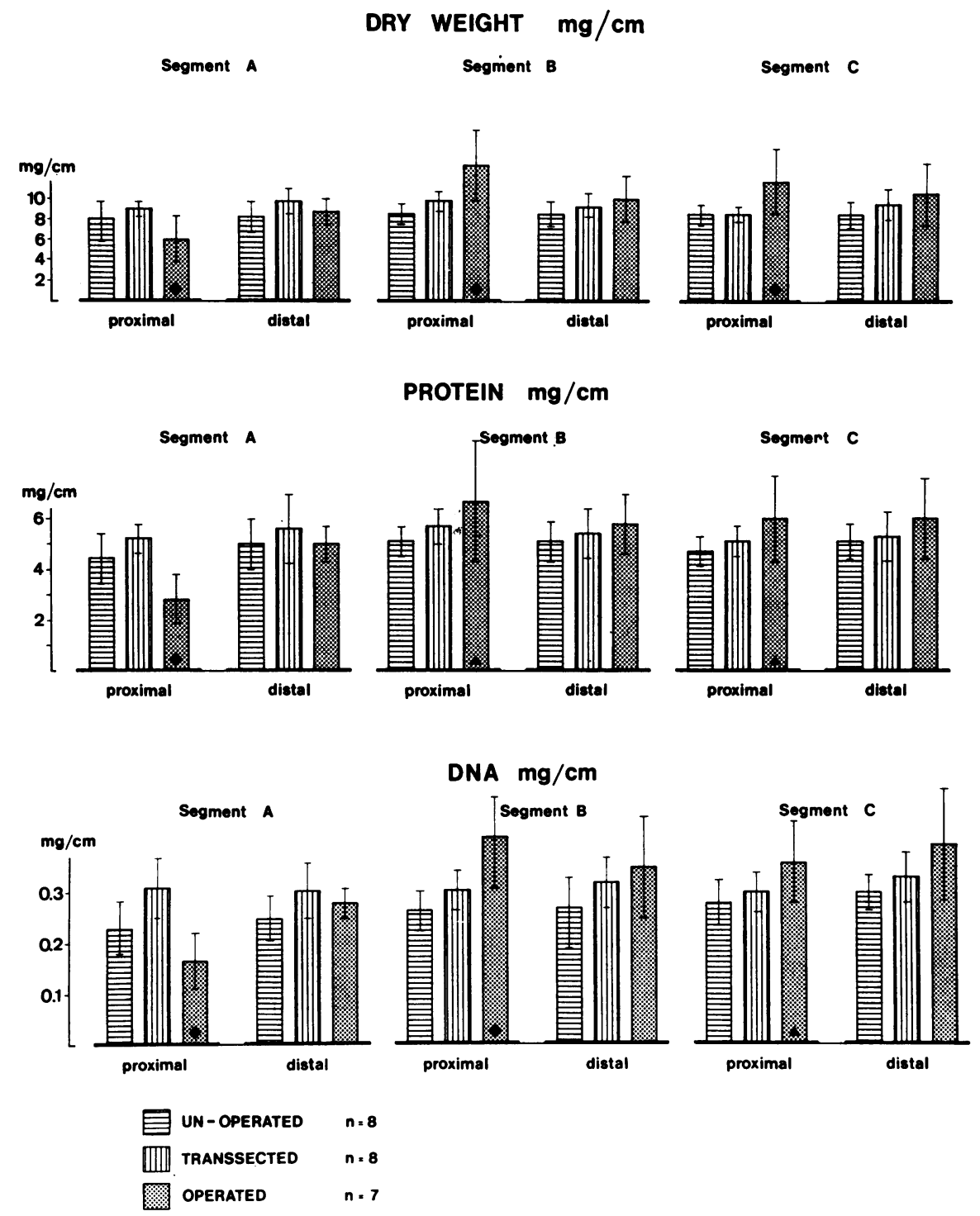

Fig. 2 Mucosal dry weight, protein, and DNA referred to unit length of intestine. There were no significant differences between the two control groups with the exception of a significantly higher DNA content in the proximal half of segment $A$ of transsected rats. $>$ : significant differences to both, non-operated and transsected rats, $\Delta:$ significant differences only to non-operated rats, $0:$ significant differences only to transsected rats. 
Table 1 Imprecision within and between run

\begin{tabular}{|c|c|c|c|c|c|}
\hline & \multicolumn{5}{|c|}{ Coefficient of variation } \\
\hline & \multicolumn{3}{|c|}{$\begin{array}{l}\text { Of imprecision within } \\
\operatorname{run}(\%)\end{array}$} & \multicolumn{2}{|c|}{$\begin{array}{l}\text { Of imprecision between } \\
\text { run }(\%)\end{array}$} \\
\hline & Runs & Mean & Range & Runs & $V_{0}$ \\
\hline \begin{tabular}{l} 
Sodium \\
Potassium \\
Protein \\
DNA \\
Glucose \\
Sucrase I \\
Sucrase II \\
Alkaline \\
\multicolumn{1}{c}{ phosphatase }
\end{tabular} & $\begin{array}{r}4 \\
4 \\
5 \\
5 \\
11 \\
2 \\
2 \\
3\end{array}$ & $\begin{array}{l}1 \cdot 49 \\
1.69 \\
5 \cdot 19 \\
2.68 \\
2.51 \\
- \\
-\end{array}$ & $\begin{array}{l}0 \cdot 61-2 \cdot 32 \\
0 \cdot 69-2 \cdot 68 \\
3 \cdot 40-6 \cdot 69 \\
1 \cdot 71-4 \cdot 09 \\
1 \cdot 33-3 \cdot 49 \\
3 \cdot 07-4 \cdot 65 \\
1 \cdot 66-3 \cdot 24 \\
2 \cdot 39-6 \cdot 76\end{array}$ & $\begin{array}{r}4 \\
4 \\
5 \\
5 \\
11 \\
11 \\
11 \\
3\end{array}$ & $\begin{array}{l}2 \cdot 62 \\
2 \cdot 91 \\
2 \cdot 91 \\
5 \cdot 05 \\
2 \cdot 47 \\
4 \cdot 98 \\
5 \cdot 30 \\
4 \cdot 70\end{array}$ \\
\hline
\end{tabular}

The imprecision within run and between run is expressed as coefficient of variation $\left(V_{c}\right)$. Sucrase $I$ and sucrase II stands for control specimens of different activity of sucrase.

experimental groups. Net absorption of sodium was significantly higher and net secretion of potassium was significantly lower in the operated rats than in both control groups with no differences between the latter (Fig. 3). In segment $C$ there were no significant differences in disappearance of galactose nor in net secretion of potassium between the three groups of rats. Net absorption of sodium was not different between transsected and operated rats, both having significantly higher net absorption of sodium than the non-operated rats (Fig. 3).

\section{Segment B}
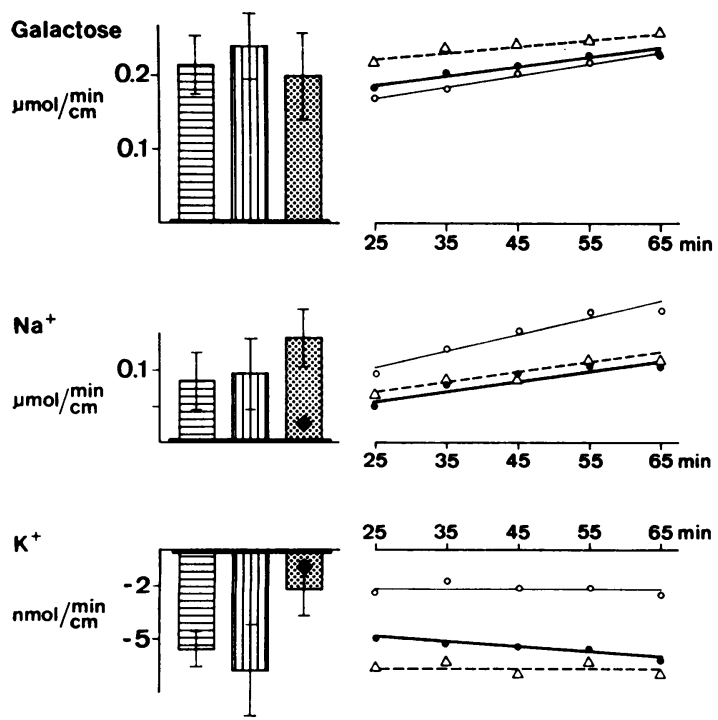

\section{ENZYME ACTIVITY}

In both halves of segment $A$ the operated rats had a reduction of sucrase activity in all reference systems. The activity of alkaline phosphatase referred to unit length of intestine was reduced only in the proximal half of segment $A$ with no change in activity referred to mucosal mass in both halves of this segment (Fig. 4, Table 2). In the operated rats in both halves of segment $B$ there was an increased activity of sucrase per unit length of intestine which was significant only when compared to the non-operated rats. The activity referred to mucosal mass did not change. The activity of alkaline phosphatase per unit length of intestine was not changed by the operation but there was a decrease in activity referred to mucosal mass which was significant only when compared to the non-operated rats (Fig. 4, Table 2). In segment C sucrase activity did not show any significant change irrespective of the reference system. In the operated rats the activity of alkaline phosphatase was significantly higher than in the two control groups but only when referred to unit length of intestine (Fig. 4, Table 2).

\section{Discussion}

The dependence of the small intestinal epithelium on the luminal nutrition is well documented (legend
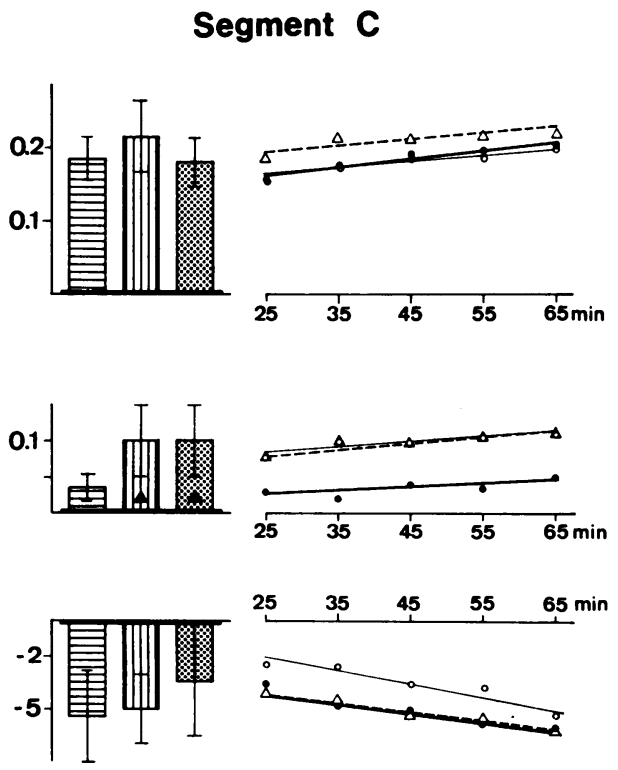

Fig. 3 Disappearance of galactose and net absorption of sodium and potassium. The only significant difference between the two control groups was a significantly higher net absorption of sodium in segment $C$ of the transsected rats. For symbols see legend to Fig. 2. 
to Table 3). Segment A of the present experimental model can be compared to the experimental conditions of intravenous feeding, self emptying blind loops and Thiry Vella loops (Table 3). Excluding the distal half of segment $A$ of the present experimental model, where some reflux from other segments might have happened, there is not a consistent difference between the four experimental conditions. The absence of luminal nutrition results in principally the same qualitative changes irrespective of the experimental condition. The present model cannot rule out an influence of bile and pancreatic juice, but it does not support the hypothesis that these secretions contain 'trophic' factors which principally modify the answer of rat jejunal epithelium to deprivation of luminal nutrition (Altmann, 1974). The experiments of Altmann and Leblond (1970) showed that the absence of bile and pancreatic secretions from gut lumen did not alter the 'villus size index' in rat jejunum as long as there was food present. This confirms our findings of a major role of luminal nutrition. The more detailed analysis of the mucosal mass in this segment (A) revealed an unequivocal reduction of mucosal mass in the proximal half of this segment. In this part of segment A Clarke et al. (1976) found only a non-significant reduction of villus height. Since in rats the villi are leaf-shaped the mass of the villi does not only depend on their height but also on their base length (Clarke, 1974a). Therefore a reduction in base length as shown in scanning electron micrographs of Thiry Vella loop mucosa (Rijke et al., 1977) can explain the reduction in mucosal mass in spite of unchanged villus height. This reduction in mucosal mass was one reason for the decreased activity referred to gut length of sucrase and alkaline phosphatase (Fig. 4). The decreased activity per mucosal mass only for sucrase but not for alkaline phosphatase indicated that there

\section{SUCRASE $\mathrm{U} / \mathrm{cm}$}

Segment A

Segment B

Segment C

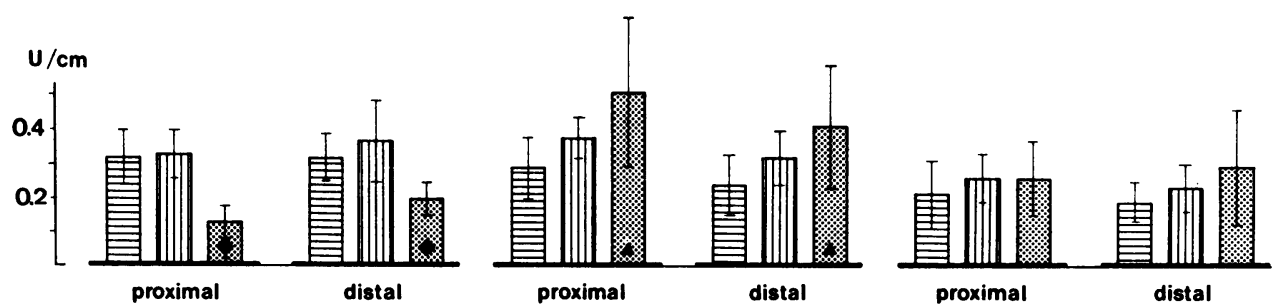

alkaline phosphatase $\mathrm{U} / \mathrm{cm}$

Segment A

Segment B

Segment C
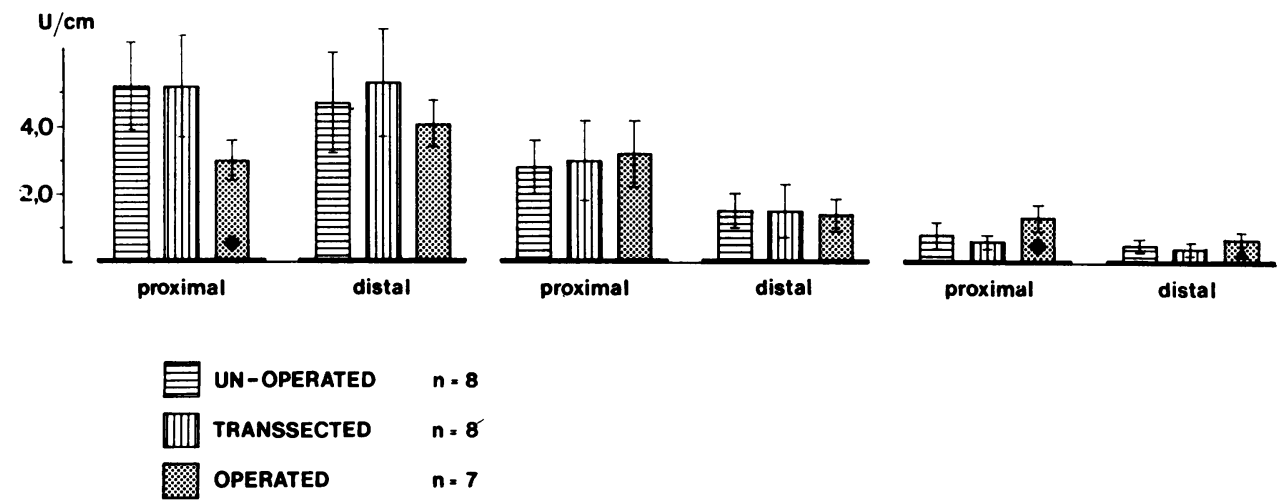

Fig. 4 Activity of sucrase and alkaline phosphatase referred to unit length of intestine. The only difference between the two control groups was a significantly higher activity of sucrase in the proximal half of segment $B$ in transsected rats. For symbols see legend to Fig. 2. 
Table 2 'Specific activity' of sucrase and alkaline phosphatase

\begin{tabular}{|c|c|c|c|}
\hline U/g PROT & Non-operated & Transsected & Operated \\
\hline \multicolumn{4}{|l|}{$\begin{array}{l}\text { A } \\
\text { Proximal }\end{array}$} \\
\hline $\begin{array}{l}\text { SA } \\
\text { ALP }\end{array}$ & $\begin{array}{c}76 \cdot 8 \pm 15 \cdot 7 \\
1206 \pm 271\end{array}$ & $\begin{array}{l}62 \cdot 6 \pm 11 \cdot 7 \\
992 \pm 217\end{array}$ & $\begin{array}{l}45 \cdot 1 \pm 18 \cdot 6(\diamond) \\
1034 \pm 263\end{array}$ \\
\hline \multicolumn{4}{|l|}{ Distal } \\
\hline $\begin{array}{l}\text { SA } \\
\text { ALP }\end{array}$ & $\begin{array}{l}65 \cdot 8 \pm 15 \cdot 1 \\
926 \pm 151\end{array}$ & $\begin{array}{c}67 \cdot 7 \pm 18 \cdot 9 \\
1029 \pm 501\end{array}$ & $\begin{array}{l}40 \cdot 5 \pm 9 \cdot 5(\diamond) \\
823 \pm 170\end{array}$ \\
\hline & & & \\
\hline $\begin{array}{l}\text { Proximal } \\
\text { SA } \\
\text { ALP }\end{array}$ & $\begin{array}{l}58 \cdot 4 \pm 21 \cdot 4 \\
569 \pm 173\end{array}$ & $\begin{array}{l}68 \cdot 4 \pm 12 \cdot 8 \\
543 \pm 209\end{array}$ & 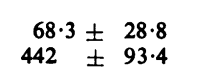 \\
\hline \multicolumn{4}{|l|}{ Distal } \\
\hline $\begin{array}{l}\text { SA } \\
\text { ALP }\end{array}$ & $\begin{array}{l}46 \cdot 9 \pm 19 \cdot 1 \\
294 \pm 73\end{array}$ & $\begin{array}{l}59 \cdot 1 \pm 11 \cdot 11 \\
275 \pm 147\end{array}$ & $\begin{array}{r}69 \cdot 0 \pm 25 \cdot 4 \\
229 \pm 53 \cdot 1\end{array}$ \\
\hline $\begin{array}{l}\text { C } \\
\text { Proximal }\end{array}$ & & & \\
\hline $\begin{array}{l}\text { SA } \\
\text { ALP }\end{array}$ & $\begin{array}{r}45 \cdot 2 \pm 19 \cdot 7 \\
157 \pm 63 \cdot 7\end{array}$ & $\begin{array}{c}51 \cdot 3 \pm 15 \\
118 \cdot 7 \pm 49.9\end{array}$ & $\begin{array}{c}45 \cdot 4 \pm 13 \cdot 0 \\
242 \pm 120 \text { (O) }\end{array}$ \\
\hline \multicolumn{4}{|l|}{ Distal } \\
\hline $\begin{array}{l}\text { SA } \\
\text { ALP }\end{array}$ & $\begin{array}{l}37 \cdot 0 \pm 11 \cdot 1 \\
93 \cdot 7 \pm 25 \cdot 3\end{array}$ & $\begin{array}{l}43 \cdot 1 \pm 9.6 \\
71 \cdot 3 \pm 31 \cdot 4\end{array}$ & $\begin{aligned} 46.0 \pm 21.8 \\
112.7 \pm 33.6(O)\end{aligned}$ \\
\hline
\end{tabular}

Expressing the data as enzyme-activity per unit dry weight or per unit weight of DNA resulted in principally the same differences between the three groups of rats as referring them to unit weight of protein. Therefore the most commonly used 'specific activity' (enzyme-activity referred to mucosal protein) was depicted. The activity of sucrase and alkaline phosphatase was abbreviated as 'SA' and 'ALP' respectively. There were no significant differences between both the control groups. The means of the specific activity of sucrase were not significantly different between proximal and distal half in any segment. With the exception of the segment $A$ in transsected and operated rats the specific activity of alkaline phosphatase was always significantly higher in the proximal half of a segment than in the distal half. For symbols see legend to Fig. 2.

were mechanisms specific for the sucrase. The preferential solubilisation of sucrase by proteolytic enzymes (Alpers and Tedesco, 1975) or deoxycholate
(Boedeker et al., 1976) and the higher resistance of alkaline phosphatase to inactivation by pancreatic proteases (Seetharam et al., 1975) might be responsible for a higher 'loss' of sucrase compared to alkaline phosphatase. A reduced rate of 'synthesis' of sucrase as a consequence of the absence of luminal carbohydrates (Castro et al., 1975; Menge et al., 1975) might further contribute to the decrease at the cellular level only for sucrase. In spite of these changes in enzyme activity a decrease in disappearance rate of galactose from gut lumen could not be observed in this segment (Ecknauer et al., 1977a). From the findings of Gleeson et al. $(1972 a, b)$ and Menge et al. (1970) it seems very probable that the time interval of one month is too short to change the absorption of the sugar investigated.

The changes in segment $B$ are difficult to interpret. This segment was brought to a more proximal position, and, as normally, was exposed to food. In investigations not yet published (Wagner, Feyerabend, and Poley) we could demonstrate a considerable reflux of pancreatic enzymes in this segment. Further on this segment was exposed to acid stomach juice (pH 3-4) which was effectively neutralised to a $\mathrm{pH}$ of 6-7. These complex changes of the luminal contents in this segment resulted in an increase in mucosal mass in the proximal half. In this part there was a large increase in gut circumference (Ecknauer et al., 1977a) which apparently caused this increase in mucosal mass in spite of unchanged, or even slightly reduced, villus height (Clarke et al., 1976). This increase in mucosal mass is the main reason for the increased activity of sucrase per unit length of

Table 3 Changes in small intestinal epithelium after deprivation of luminal nutrition

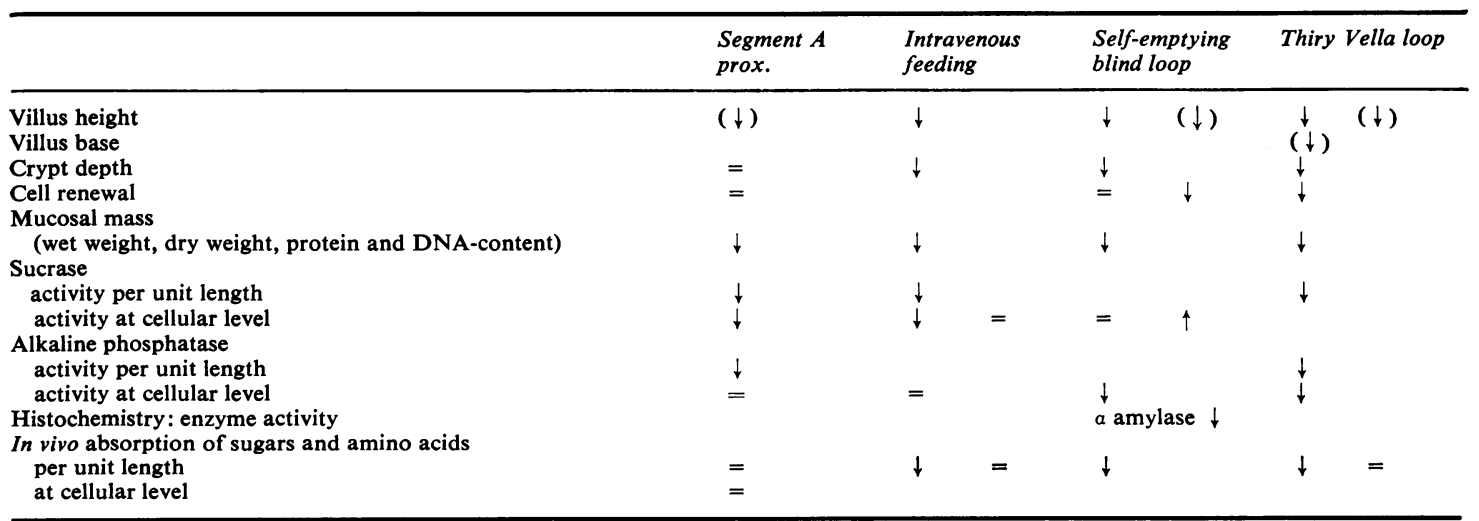

The symbols used indicate an increase $\uparrow$, no change $=$, or a decrease $\downarrow$ in the results of the experimental condition compared with the results of the corresponding control group. When in parentheses the changes were judged only qualitatively. The morphological data have to be considered both as length and as number of cells per section.

Intravenous feeding: Bury et al. (1975), Castro et al. (1975), Johnson et al. (1975), Levine et al. (1974), Dworkin et al. (1976).

Self-emptying blind loops: Clarke (1974b), Fenyö and Hallberg (1976), Giannella et al. (1974), Gleeson et al. (1972a,b), Menge et al. (1970).

Thiry Vella loop: Clarke (1974b), Gleeson et al. (1972a,b), Hietanen and Hänninen (1972). 
intestine as indicated by the unchanged activity referred to mucosal mass. The activity of alkaline phosphatase, on the other hand, was not changed when referred to unit length of gut but decreased when referred to mucosal mass, indicating a reduction at the cellular level. There were no changes in disappearance of galactose but remarkable changes in the handling of electrolytes. Changes in the activity Na-K-ATPase (Hietanen and Hänninen, 1972; Tilson and Wright, 1972) alteration of the unstirred layer, in the number of absorbing cells or in the tightness of the epithelial layer can be discussed as reason for the altered handling of the electrolytes.

The changes in the segment $C$ were smaller than those in the previous investigation (Ecknauer et al., 1977a); this is most probably because of the shorter length of the excluded segment $(A)$ in the present study. The changes are compatible with the hypothesis that this segment represents a distal gut segment brought to a more proximal position (Dowling, 1974; Menge et al., 1976; Tilson and Wright, 1972).

The authors are indebted to Ms J. Breitsameter for skilfully performing the experiments and analyses and to Ms I. Hössle for calculation and statistical comparison of the data. This is the third report of a multidisciplinary research group granted by the Deutsche Forschungsgemeinschaft (SFB 112 E4). We thank all members of this group, particularly Professor K. Rommel, for co-operation and stimulating discussions.

\section{References}

Alpers, D. H., and Tedesco, F. J. (1975). The possible role of pancreatic proteases in the turnover of intestinal brush border proteins. Biochimica Biophysica Acta, 401, 28-40.

Altmann, G. G. (1974). Demonstration of a morphological control mechanism in the small intestine. Role of pancreatic secretions and bile. In Intestinal Adaptation, pp. 75-85. Edited by R. H. Dowling and E. O. Riecken. Schattauer: Stuttgart.

Altmann, G. G., and Leblond, C. P. (1970). Factors influencing villus size in the small intestine of adult rats as revealed by transposition of intestinal segments. American Journal of Anatomy, 127, 15-36.

Boedeker, E. C., Higgins, Y. K., Donaldson, R. M., Jr., and Small, D. M. (1976). Selective solubilization of enzyme proteins from microvillus membranes (MVM) using non-ionic and anionic detergents (Abstract). Gastroenterology, 70, 865.

Bury, K. D., Grayston, M., and Kanarens, J. (1975). Characteristics of intestinal absorption following prolonged total parenteral nutrition. Surgical Forum, 26, 22-24.

Castro, G. A., Copeland, E. M., Dudrick, S. J., and Johnson, L. R. (1975). Intestinal disaccharidase and peroxidase activities in parenterally nourished rats. Journal of Nutrition, 105, 776-781.

Clarke, R. M. (1974a). Morphological description of in- testinal adaptation: measurements and their meanings. In Intestinal Adaptation, pp. 11-16. Edited by $\mathbf{R}$. $\mathbf{H}$. Dowling and E. O. Riecken. Schattauer: Stuttgart.

Clarke, R. M. (1974b). Control of intestinal epithelial replacement: lack of evidence for a tissue-specific bloodborne factor. Cell Tissue Kinetics, 7, 241-250.

Clarke, R. M., Ecknauer, R., and Feyerabend, G. (1976). An analysis of the effects of food and of digestive secretions on the small intestine of the rat. I. Mucosal morphology and epithelial replacement. Gut, 17, 895-899.

Dowling, R. H. (1974). The influence of luminal nutrition on intestinal adaptation after small bowel resection and bypass. In Intestinal Adaptation, pp. 35-45. Edited by R. H. Dowling and E. O. Riecken. Schattauer: Stuttgart.

Dworkin, L. D., Levine, G. M., Farber, N. J., and Spector, M. D. (1976). Small intestinal mass of the rat is partially determined by indirect effects of intraluminal nutrition. Gastroenterology, 71, 626-630.

Ecknauer, R., Clarke, R. M., and Feyerabend, G. (1977a). An experimental model for studies on the effects of food and digestive secretions on the digestive-absorptive capacity of rat small intestine. Journal of Clinical Chemistry and Clinical Biochemistry, 15, 361-366.

Ecknauer, R., Rommel, K., Schnösenberg, I., and Breitsameter, J. (1977b). Measurement of enzyme activity and substrates in intestinal mucosa. Evaluation of a system for quality control in clinical and experimental gastroenterology. Acta Hepato-Gastroenterologica, 24, 182-192.

Fenyö, G., and Hallberg, D. (1976). Intestinal hypertrophy after small intestinal bypass in the rat. Acta Chirurgica Scandinavica, 142, 261-269.

Giannella, R. A., Rout, W. R., and Toskes, P. P. (1974). Jejunal brush border injury and impaired sugar and amino acid uptake in the blind loop syndrome. Gastroenterology, 67, 965-975.

Gleeson, M. H., Cullen, J., and Dowling, R. H. (1972a). Intestinal structure and function after small bowel bypass in the rat. Clinical Science, 43, 731-742.

Gleeson, M. H., Dowling, R. H., and Peters, T. J. (1972b). Biochemical changes in intestinal mucosa after experimental small bowel bypass in the rat. Clinical Science, 43, 743-757.

Hietanen, E., and Hänninen, O. (1972). Effect of chyme on mucosal enzyme levels in small intestine of the rat. Metabolism, 21, 991-1000.

Johnson, L. R., Copeland, E. M., Dudrick, S. J., Lichtenberger, L. M., and Castro, G. A. (1975). Structural and hormonal alterations in the gastrointestinal tract of parenterally fed rats. Gastroenterology, 68, 1177-1183.

Levine, G. M., Deren, J. J., Steiger, E., and Zinno, R. (1974). Role of oral intake in maintenance of gut mass and disaccharidase activity. Gastroenterology, 67, 975-982.

Menge, H., Bloch, R., Schaumlöffel, E., and Riecken, E. O. (1970). Transportstudien, morphologische, morphometrische und histochemische Untersuchungen zum Verhalten der Dünndarmschleimhaut im operativ ausgeschalteten Jejunal abschnitt der Ratte. Zeitschrift für die Gesamte Experimentelle Medizin, 153, 74-90.

Menge, H., Robinson, J. W. L., and Riecken, E. O. (1976). Anpassungsmöglichkeiten der Dünndarmschleimhaut an verschiedene intraluminale Milieuveränderungen. Zeitschrift für Gastroenterologie, 14, 420-433.

Menge, H., Werner, H., Lorenz-Meyer, H., and Riecken, E. O. (1975). The nutritive effect of glucose on the structure and function of jejunal self-emptying blind loops in the rat. Gut, 16, 462-467.

Rijke, R. P. C., Plaisier, H. M., De Ruiter, H., and Galjaard, H. (1977). The influence of experimental bypass on cellular kinetics and maturation of small intestinal epithelium in the rat. Gastroenterology, 72, 896-901. 
Seetharam, B., Goodwin, C., Grimme, N., and Alpers, D. H. (1975). The differing effects of proteases in enzymes of human intestinal microvillus membrane (Abstract). Gastroenterology, 68, 1053.

Tilson, M. D., and Wright, H. K. (1979). Adaptional changes in ileum following jejunectomy. In Regulation of Organ and
Tissue Growth, pp. 257-270. Edited by R. J. Goss. Academic Press: New York.

Welch, B. L. (1947). The generalization of 'Student's' problem when several different population variances are involved. Biometrika, 34, 28-35. 